Original Research Paper

\title{
The Impacts of Administrative Structure on the Functions of Local Government in Nigeria (a Study of Ikorodu Local Government)
}

\author{
Olasunkanmi Olusogo Olagunju \\ Department of Political Science, University of Lagos, Nigeria
}

Article history

Received: 09-10-2018

Revised: 31-12-2018

Accepted: 18-06-2019

Tel: +2348101223865

Email:justpolitical12345@gmail.com

\begin{abstract}
This research paper is an attempt to explicitly investigate the relationships between administrative structures and functions of Nigeria's local government. It will succinctly define the concept of local government, its history and the objectives of establishing grassroots government in Nigeria. Having adopted both primary and secondary means of data collection, this paper will therefore examine how the local government strives to deliver essential public services at the grassroots level. It will also seek to examine how coherent administrative structure has aided the effective and efficient performance of the administrative functions of Nigerian local government. Apart from explaining the basic objectives of local government in Nigeria, the paper will therefore conclude that the structures of local government are vital to the effectiveness and efficiency in performing its functions and thereby make some recommendations to help Nigerian local government perform its statutory functions.
\end{abstract}

Keywords: Local Government, Administration, Reforms, Service and Council

\section{Introduction}

As a federal system of government, Nigeria is made up of three tiers of government (Ozohu-Suleiman and Paul, 2015). Being a federal nation means that power and responsibilities are divided between the federal, state and local government. Hence, local government receives its power from the constitution which divided the country into three tiers of government (Otinche, 2014). The need for the establishment of local government in Nigeria came out of the quest to deliver certain basic services that are instrumental for survival of the people at the grassroots level (Adeyemi, 2013). However, every local government varies in size and structure (Chukwuemeka et al., 2014). More so, local government is universally regarded as the nearest institution to the people at the grassroots which is specifically involved in the task of governance and service delivery at the local units.

As a matter of fact, local government is usually founded upon the premise that as the sub-unit of government it will stimulate popular participation in developmental and political activities (Adeyemi, 2012). This is more reason why every local government in Nigeria including Ikorodu Local Government requires a coherent administrative structure that will aid the efficient performance of its statutory functions. The desire for coherent structure for Nigeria local governments is reinforced out of the fact that they are the potent tiers of government for grassroots development. It is against this that Chukwuemeka et al. (2014); Otinche (2014); Ezeani (2006) and Tumini (2011) argued that the presence of coherent administrative structures is very pivotal for service delivery in Nigeria local government.

However, various administrations and regimes have strived to bestow instituional structure to Nigeria's local governments but Muritala-Obasanjo regime was more fundamental because it brought structures that have aided the efficient delivery of statutory functions of the local governments (Ajayi, 2000; Anifowose and Enemuo, 1999). However, Obasanjo judiciously continued the reform programme for Nigeria's local government in spite of the assassination of Muritala Mohammed in a failed coup in 1976. The 1976 local government reformsperceived local government as government at the local level exercised through representative council established within defined areas (Federal Government of Nigeria, 1976; 1999). Local government in Nigeria began to assume development roles through the 1976 local government reforms (Tumini, 2011). 
According to Anifowose and Enemuo (1999), the 1976 reforms gave local government in Nigeria the powers to embark on discharging its developmental functions; institutional and financial powers to initiate and direct the provision of services; and to determine and implement programmes so as to complement the activities of the state and federal government in their local jurisdictions. It can deduced from the foregoing that the administrative structures of Nigeria local governments is instrumental to the provision of pipeborne water, good local roads, primary health care and education at the local units.

\section{History of Local Government in Nigeria}

It is important to understand that the origin of local government in Nigeria can be traced to the colonial era when the British imperial government needs to push governance to the local districts (Wikipedia, 2018). Nigeria is complex and diverse country with massive population (Akani, 2017) and this calls for a tier of government that can bring service delivery and developmental functions to the local inhabitants.

Between 1960 and 1966, there was lack of uniformity in the governance of local units in Nigeria. The country had for some time witnessed a decline in the developmental functions and responsibilities of local authorities. In the former Western region, the local government (Amendment) law 1960 abolished the powers of councils to impose levy on education and general rates on the basis of need. In Lagos, there was a high rate of default in the payment of property rates including government institutions, which reduced the revenue of the local councils (Rabiu, 2004).

Prior to the local government reform in 1976, the local government lacks the requisite administrative structures that will facilitate the discharge of the developmental functions of this lower tier of government. Inthe Eastern and Northern Nigeria, there were gradual changes in the structure of the local councils with increasing numbers of elected or appointed non-traditional council members becoming members of local authorities (Chukwuemeka et al., 2014). The result was that the local authorities had a stable administrative structure, which enabled them to assume functional responsibilities, with some degree of success in the delivery of some complex services like establishment of local markets and primary schools, construction of local roads and delivery of certain amenities that are germane to human survival and economic growth in the local units (Tumini, 2011).

Between 1969/71, some state governments had introduced some changes in the structure of their councils; however, it was in 1976 that the Federal Government in collaboration with the state governments embarked on extensive reforms of local government administrative structures in Nigeria as a panacea for enhancing the efficient discharge of the statutory functions of the third tier of government in Nigeria. It can be deduced that from 1976 to the present political dispensation, the administrative structures of local government had practically remained unchanged thereby contributing immensely to efficiency in the discharge of constitutional mandates of local government in Nigeria.

\section{Conceptual Definitions}

Local government refers to a political sub-division, which are created within a state for the exercise of duties and responsibilities granted by constitutional provisions or legislative enactments (Adamolekun, 1988). It also represents a political authority which is specifically established by law or constitution for local communities by which they manage their public affairs within the limits of the law (Odion-Akhaine, 2009:27).

Local governments are infra-sovereign geographic units found within sovereign nation or quasi-sovereign state. According to Ola and Tonwe (2005:2), local government can be defined as the third tier of government which is instrumental to grassroots development. In addition, local government can be defined as a political subdivision of a nation which is primarily constituted by constitution and has extensive control over local affairs including powers to impose taxes or exact labour laws for predetermined purposes (Odion-Akhaine, 2009:287).

Like other units of governments, local governments possess a defined area, a population, an organisation, also the authority to undertake and the power to perform public activities. According to Anifowose and Enemuo (1999), local government is the smallest unit of administration in any political system. However, it represents the lowest level of government in a modern state structure that is legally distinct with powers to raise its own revenue and to undertake delegated responsibilities as provided for by the constitution.

It is the lowest level through which representative government can be practiced (Ojofeitimi, 2000). In Nigeria, there are three-tier of government, that is, Federal, State and Local Government. The local government is the third-tier of government and that placed it in a position of nearness to the people at the grassroots or local communities. Akani (2017) defined local government as a political body statutorily created by law to govern the local communities basically through an organized and systematic process to achieve the objectives of grassroots development.

Its closeness to the local populace enables it to perform special functions and services, which bother on the interests and aspirations of the local communities. Blair defined local government as an organisation with a resident population occupying a defined area that has a 
usually authorized organisation and government body;a separated legal entity, the power to provide certain public or governmental services and a substantial degree of autonomy including legal or actual power to raise part of its own revenue.

\section{Theoretical Framework}

The paper will adopt the "institutional theory" as the theoretical framework for the analysis of the impacts of administrative structures on the functions of local government in Nigeria. Although several theories exist on the succinct analysis of the research work, but this research work will consider local government as the third institution of government for the delivery of certain functions targeted at alleviating the socio-economic quagmires of the grassroots people. However, institutional theory can be construed as one of the deeper and more durable aspects of any social structure. It considers the processes by which structures which include rules, schemes, norms and routines become established as authoritative guidelines for social behaviour. It should be understood that diverse components of institutional theory describe how these elements are created, diffused, adopted and adapted over space and time; and how they fall into decline and disuse.

In the definition of institutions, according to Scott (2004:235), there exists "no single and universally agreed definition of an institution in the school of thought." Scott (2004:48) explained that institutions consist of social structures which have attained a high degree of resilience. They also consist of normative and regulative elements that, together with associated activities and resources, give stability and definite meaning to social life. More so, it can be explained that institutions are basically transmitted by various types of carriers which include the symbolic systems, relational systems, routines and artifacts. Hence, institutions operate at diverse levels of jurisdiction. According to Scott (2008), what is known as institutional theory is an extensively acceptable theoretical postulation that focuses on rational myths, isomorphism and legitimacy.

From this foregoing, local government can be viewed as the institution of government responsible for carrying out certain developmental functions at the grassroots level of government. Hence, the reforms or amendment to the administrative structure of Nigeria local government is an attempt to enhance the institutional structure of local government for a better delivery of developmental and growth functions in the local level of government in the country. However, certain amenities are needed for the growth and development of the local ecosystem of Nigeria, these involve the delivery of social amenities, better roads, agricultural inputs, pipe-borne water and numerous others which can only be adequately delivered by appropriate government's institutions. Hence, it is against this background that local governments can be denoted as the most potent institutional organ of government which requires effective structure to be able to deliver the needed socioeconomic amenities to ameliorate the quagmires of the local inhabitants of Nigeria.

\section{The Empirical Literature Review}

Apart from the fact that Table 1 in this research paper had shown that the administrative structure of local government has impacts on its ability to perform its administrative functions more efficiently in Nigeria,it should be clearly noted that local governments in Nigeria are mostly established to achieve the grassroots agenda of government (Onuigbo and Eme, 2015). Deriving from the 1976 Local Government Reforms, it can be inferred that the objectives for establishing local government in Nigeria can be summarized below. These actually include the followings:

- To make appropriate services and development activities responsive to local wishes and initiatives by developing or delegating such services to local representatives bodies;

- To facilitate and bring the exercise of democratic selfgovernance close to the local levels of our society and to encourage at the local level initiative and leadership potentials; and

- To mobilize human and material resources through the involvement of member of the public in their local government and to provide a two-way channel of communication between local communities (both state and federal).

\section{Administrative Functions of Nigeria's Local Government}

Table 2 and 3 statistically validatedour postulation on the impacts of apposite administrative structures of local government in Nigeria. Itcan therefore be deduced that Nigeria local government council delivers a variety of functions based on its ability to generate revenue within its statutory jurisdiction (Anifowose and Enemuo, 1999). Some of the numerous functions perform by Nigeria local government council includes the followings, viz:

- Nigeria's local government council discharges the administrative functions that have to do with the provision and promotion of sustainable management of health services and system

- Another administrative function which Nigeria's local government council performs is mainly the security of human lives and property and this is built on the quest to protect and perpetuate human lives by creating and funding some neighbourhood vigilantes especially in some dangerous neighbourhoods 
- Nigeria's local government is also instrumental to poverty alleviation and women empowerment in the local areas through the mobilisation and allocation of funds (Rabiu, 2004). This is more reason why there is the prevalence of loan schemes and cooperative societies which have created soft loans to the small and medium scale entrepreneurs. Women centres are widespread in diverse local governments in Nigeria to empowerwomenin their both personal and collective endeavours and forged a way to pull resources together to collectively fund some projects

- As a grassroots agent of development, Nigeria's local government council is charged with the responsibilities of providing certain light-weight amenities such as local roads and other amenities to better the lives of the grassroots inhabitants (Anifowose and Enemuo, 1999). In the same vein, certain pipe-borne water and boreholes have been constructed while several local governments in Nigeria have spearheaded the establishment of some maternity centres. They usually enter into jointly implemented projects particularly in the areas of infrastructure for neighbourhood development as well as the overall growth of the country

- In order to properly monitor progress on the ongoing projects, Nigeria's local government council often makes available official vehicles to both the political office holders and field workers to efficiently and productively deliver on their mandates. Nigeria's local governments have recorded substantial successes in areas of creating enabling environment for economic growth, political stability, security of lives and human capital development. Some projects such as education, construction, health and women empowerment projects are made available to some local districts

- Nigeria's local government councils also ensure the provisions of free training particularly for the women and youths. There are varieties of development centres; it also provides free education materials to some schools administered by the local authority. There are many instances when the local council sponsored scholarships and awards for excellence in education and local participation in community projects and development. Some local councils often provide free equipment in primary health centres, schools and vocational centres; it also performs it administrative function of providing a handful of skills acquisition programmes in handicrafts especially in fashion designing, painting, carpentry, brick-laying, shoe making, catering to mention but a few. This is the human capacity development programme which forms part of capital expenditure of Nigeria's local government

\section{Gaps in Literatures}

It should be understood that this research work seeks to resolve the impacts of some problems on the structure and functions of local government in Nigeria. Some of problems include corruption, public mismanagement and unprofessional attitude of local government officials in discharging their constitutional duties. Nigeria local government has been marred by the problem of shortage of adequate revenue needed for service delivery at the grassroots level while some of them are been neglected by the central government. Also included among these problems of Nigeria local government is the lack of accountability, transparency and probity on part of the staffs. All these problems have critically bedeviled the strength and power of Nigeria local government to efficiently deliver their constitutional functions and thereby rendering the administrative structures more impotent.

\section{Results and Analysis of Data}

This research work make use of standardized questionnaires to sample the opinions and responses of 120 staffs of Ikorodu Local Government Council on their perception on the impacts of the administrative structures on the functions of local government in Nigeria. It is important to understand that 100 questionnaires were returned owing to some inevitable limitations. The tables below represent the respondents' opinions on the impacts of administrative structures on the functions of local government in Nigeria, viz:

The demographic composition of the respondents was not considered important to the analysis. Table 1 shows the results of the responses of the staffs which were recorded as follow: in questionnaire item 1 namely: the administrative structure of local government has impacts on its ability to performs its administrative functions more efficiently in Nigeria, the respondent noted strongly agree (50), agree (38), disagree (11) and strongly disagree (1) with a mean of 1.63. This implies that most of the respondents are of the view that the administrative structure of local government has impacts on its ability to perform its administrative functions more efficiently in Nigeria. The questionnaire item 2 namely local government is very instrumental to grassroots development in Nigeria had the respondents noted strongly agree (50), agree (35), disagree (11) and strongly disagree (4) with a mean of 1.69. This implies that most of the respondents are of view that namely local government is very instrumental to grassroots development in Nigeria. 
Table 1: Analysis of responses to the research questions

\begin{tabular}{|c|c|c|c|c|c|c|c|}
\hline $\mathrm{S} / \mathrm{N}$ & Local government structures & SA & A & $\mathrm{D}$ & SD & $\mathrm{X}$ & DECISION \\
\hline \multirow[t]{2}{*}{1} & The administrative structure of & 50 & 38 & 11 & 1 & \multirow[t]{2}{*}{1.63} & \multirow{2}{*}{$\begin{array}{l}\text { Strongly } \\
\text { agree }\end{array}$} \\
\hline & $\begin{array}{l}\text { local government has impacts on its } \\
\text { ability to perform its administrative } \\
\text { functions more efficiently in Nigeria. }\end{array}$ & $50 \%$ & $38 \%$ & $11 \%$ & $1 \%$ & & \\
\hline \multirow[t]{2}{*}{2} & Local government is very instrumental to & 50 & 35 & 11 & 4 & \multirow[t]{2}{*}{1.69} & \multirow{2}{*}{$\begin{array}{l}\text { Strongly } \\
\text { agree }\end{array}$} \\
\hline & grassroots development in Nigeria. & $50 \%$ & $35 \%$ & $11 \%$ & $4 \%$ & & \\
\hline \multirow[t]{2}{*}{3} & Efficient service delivery in Nigeria's & 43 & 36 & 15 & 6 & \multirow[t]{2}{*}{1.84} & \multirow{2}{*}{$\begin{array}{l}\text { Strongly } \\
\text { agree }\end{array}$} \\
\hline & $\begin{array}{l}\text { local government depends on its access to } \\
\text { independent revenue generation. }\end{array}$ & $43 \%$ & $18 \%$ & $15 \%$ & $6 \%$ & & \\
\hline \multirow[t]{2}{*}{4} & Without coherent structure Nigerian & 45 & 31 & 16 & 8 & \multirow[t]{2}{*}{1.87} & \multirow{2}{*}{$\begin{array}{l}\text { Strongly } \\
\text { agree }\end{array}$} \\
\hline & $\begin{array}{l}\text { local government willnever deliver on } \\
\text { its mandates to local inhabitants }\end{array}$ & $45 \%$ & $31 \%$ & $16 \%$ & $8 \%$ & & \\
\hline
\end{tabular}

Source: Field Work (2018)

Table 2: Local government functions

\begin{tabular}{|c|c|c|c|c|c|c|c|}
\hline & Local Government Functions & & & & & & \\
\hline \multirow[t]{2}{*}{$\overline{5}$} & Local government reforms have & 41 & 34 & 13 & 12 & 1.96 & Strongly \\
\hline & $\begin{array}{l}\text { played essential roles in the } \\
\text { development of local units in Nigeria. }\end{array}$ & $41 \%$ & $34 \%$ & $13 \%$ & $12 \%$ & & Agree \\
\hline \multirow[t]{2}{*}{6} & The administrative structure of local & 15 & 18 & 16 & 51 & 3.03 & Strongly \\
\hline & $\begin{array}{l}\text { government has no impact on its ability } \\
\text { to perform its administrative functions in Nigeria. }\end{array}$ & $15 \%$ & $18 \%$ & $16 \%$ & $51 \%$ & & Disagree \\
\hline \multirow[t]{2}{*}{7} & The problems of corruption and fraud are bad for & 45 & 30 & 15 & 10 & 1.93 & Strongly \\
\hline & local government development in Nigeria. & $45 \%$ & $30 \%$ & $15 \%$ & $10 \%$ & & Agree \\
\hline \multirow[t]{2}{*}{8} & The development of Nigeria's local government & $45 \%$ & 28 & 17 & 10 & 1.92 & Strongly \\
\hline & $\begin{array}{l}\text { has been affected by lack of qualified manpower } \\
\text { for revenue generation. }\end{array}$ & $45 \%$ & $28 \%$ & $17 \%$ & $10 \%$ & & Agree \\
\hline
\end{tabular}

Source:Fieldwork, (2018)

Table 3: Test statistics

The administrative structure of local government has impacts

on its ability to performs its administrative functions more efficiently in Nigeria

\begin{tabular}{lr}
\hline Chi-Square & $62.640^{\mathrm{a}}$ \\
Degree of Freedom & 3.000 \\
Asymptotic Significance & 0.000 \\
\hline
\end{tabular}

a. 0 cells $(.0 \%)$ have expected frequencies less than 5 .

b. The minimum expected cell frequency is 25.0. Source: Computerised SPSS Result

In questionnaire item 3 namely efficient service delivery in Nigeria's local government depends on its access to independent revenue generation, the respondent noted strongly agree (43), agree (36), disagree (15) and strongly disagree (6) with the mean of 1.84 . This implies that most of the respondents are of view that efficient service delivery in Nigeria's local government depends on its access to independent revenue generation. The questionnaire item 4 namely without coherent structure Nigerian local government will never efficiently deliver on its mandates to local inhabitants the respondent noted strongly agree (45), agree (31) and disagree (16) and strongly disagree (8) with the mean of 1.87 . This implies that most of the respondents are of view that without coherent structure Nigerian local government will never efficiently deliver on its mandates to local inhabitants.

Table 2 in this research paper focuses on the local governments in Nigeria and the efficient delivery of their functions. In questionnaire item 5 namely local government reforms have played essential roles in the development of local units in Nigeria, the respondents noted strongly agree (41), agree (34), disagree (13) and strongly disagree (12) with the mean of 1.96. This implies that most of the respondents are of view that local government reforms have played essential roles in the development of local units in Nigeria. In questionnaire item 6 namely: the administrative structure of local government has no impact on its ability to performs its administrative functions more efficiently in Nigeria, the respondent noted strongly agree (15), agree (18), disagree (16) and strongly disagree (51) with a mean of 3.03. This implies that most of the respondents reject the view that revenue generation has no significant effect on the capacity of local government to deliver public service in Nigeria.

The questionnaire item 7 namely the problems of corruption and fraud are bad for local government 
development in Nigeria had the respondents noted strongly agree (45), agree (30), disagree (15) and strongly disagree (10) with a mean of 1.93. This implies that most of the respondents are of view that the problems of corruption and fraud are bad for local government development in Nigeria. In questionnaire item 8 namely The development of Nigeria's local government has been affected by lack of qualified manpower for revenue generation, the respondents noted strongly agree (45), agree (28), disagree (17) and strongly disagree (10) with the mean of 1.92. This implies that most of the respondents are of view that the development of Nigeria's local government has been affected by lack of qualified manpower for revenue generation.

\section{Interpretation of the Hypothesis Testing}

Table 3 shows that the critical value of chi-square $\left(X^{2}\right.$ - tab) is lesser than chi-square calculated $\left(X^{2}-C a l\right)$, that is, $\left(\mathrm{X}^{2}-\mathrm{Cal}=62.640>\mathrm{X}^{2}-\mathrm{Tab}=7.815\right)$. Hence, we accept the alternative hypothesis (Hi) that the administrative structure of local government has impacts on its ability to performs its administrative functions more efficiently in Nigeria. Furthermore, the Asymptotic Significance probability of not accepting this result is zero (0). Therefore, the result of the analysis shows that the administrative structure of local government has impacts on its ability to perform its administrative functions more efficiently in Nigeria which totally agrees with the premises of this research paper.

\section{Conclusion}

This paper concludes that the administrative structure of Nigeria's local government is instrumental to the discharge of its administrative functions in the country. The administrative structure gave Nigerian local government a unified structure that defines its line of authority or division of labour and responsibility among the local bureaucrats and the legislatures. This local government has been able to achieve significant successes from the grassroots development projects owing to the predominant of coherent structure of administration. When a local government has coherent structure, it will allow the flow of information on the how to implement the development goals and objectives set in the agenda.

The paper also concludes that when a local government is has good structure it will boost its capacity for productivity and performance because the line of communication has been clearly stated in the structure. However, it can be concluded that local governments in Nigeria need appropriate structure that make will equip them for sustainable provision of health care centres, local authority schools, local markets, pipeborne waters and other safety and prosperity needs of the grassroots people. However, it will be suggested that policy reforms or reformative planning will be necessary to further enhance the administrative structure of local government for efficient discharge of statutory functions.

\section{Acknowledgement}

I am highly grateful to Almighty God who have made this research a success. I also expressed my thanks to the editors and reviewers who have taken their time to assist me on this paper. To my fellow researchers I also owe a vote of thanks.

\section{Ethics}

The research paper is a robust endeavour that combined both field work and review of available literatures. All the references are properly cited. However, some of the materials used can only be reproduced at the approval of authors. The only ethical issue is how to guide against piracy and unlawful duplication of the research material. I urge the administration of Science Publications to notify me in case of any other ethical matters that may be noted.

\section{References}

Adamolekun, L., 1988. Local government in West Africa since independence. Lagos: University of Lagos Press.

Adeyemi, O., 2012. Corruption and local government administration in Nigeria: A discourse of core issues. Eur. J Sustainable Development, 1: 183-198.

Adeyemi, O., 2013. Local government and the challenges of service delivery: The Nigeria experience. J. Sustainable Development Africa, 15: 84-98.

Ajayi, K., 2000. Justification and Theories of Local Government. In: Theory and Practice of Local Government, Ado-Ekiti, Ajayi, K. (Ed.). University of Ado-Ekiti.

Akani, E.C., 2017. Local government administration and grassroots development in Nigeria: A theoretical appraisal. J. Political Science Leadership Res.

Anifowose, R. and F. Enemuo, 1999. Elements of politics. Lagos: Malthouse Press Ltd.

Chukwuemeka, E., B.I. Ugwuanyi, P. Okolo and C.E. Onuoha, 2014. Nigeria local government: A discourse on the theoretical imperatives in a governmental system. Afr. Rev. Int. Multidisciplinary J., 8: 305-324.

Ezeani, E.O., 2006. Fundamentals of public administration. Enugu: Snaap Press Ltd.

Federal Government of Nigeria, 1976. Guidelines for the reform of local government in Nigeria. Lagos, Federal Government Press.

Federal Government of Nigeria, 1999. Constitution of the federal republic of Nigeria. Lagos: Federal Government Printer. 
Odion-Akhaine, S., 2009. Local government administration in Nigeria: Old and new visions. Lagos: Centre for Constitutionalism and Demilitarization.

Ojofeitimi, T., 2000. Managing at the grassroots: Local government and rural development in the 21th Century. Lagos: Centre for Management Development.

Ola, R.O.F. and D.A. Tonwe, 2005. Local administration and local government in Nigeria. Lagos: Anifitop Books.

Onuigbo, R.A. and O.I. Eme, 2015. An analysis of the dilemma of local government in Nigeria from colonial times till date. Int. J. Manag. Stud. Res., 3: 200-221.

Otinche, S.I., 2014. Fiscal policy and local government administration in Nigeria. Int. Multidisciplinary J. Ethiopia, 8: 118-137.

DOI: 10.4314 afrrev.v8i2.8
Ozohu-Suleiman, A. and C. Paul, 2015. Local government administration in Nigeria: The Search for Relevance. World Engineering Applied Sci. J., 6: 70-77. DOI: $10.5130 /$ cjlg.v0i18.4850

Rabiu, S.A., 2004. Personal Income Tax in Nigeria Procedures and Problem, 1st Edn., Adebanjo Publishers Limited.

Scott, W.R., 2004. Institutional Theory. In: Encyclopedia of Social Theory, Ritzer, G. (Ed.). Thousand Oaks CA: Sage Publications.

Scott, W.R., 2008. Institutions and Organisations: Ideas and Interests. Los Angeles, CA: Sage publications.

Tumini, D.G., 2011. Local Government in Nigeria: An overview of Structures and Functions. In: Key Issues in Local Government and Development: A Nigerian Perspective Enugu, Tony, O. (Ed.), Praise House Publishers.

Wikipedia, 2018. Local Government. www.wikipedia.org/wiki/local-government. 